\title{
Penentuan Alternatif Alat Tangkap Ramah Lingkungan untuk Keberlanjutan Perikanan Tangkap di Kabupaten Kubu Raya
}

\author{
Determine of Alternative Eco-friendly Fishing Gear for \\ Suistainable Capture Fisheries in Kubu Raya Regency
}

\author{
Onesimus Dhyas Dwi Atmajaya ${ }^{1^{*}}$, Rosyadi ${ }^{2}$, Muhammad Hisyam $^{3}$
}

${ }^{1}$ Politeknik Negeri Sambas

${ }^{2}$ Universitas Tanjungpura Pontianak

${ }^{3}$ Universitas Brawijaya Malang

\section{Info Artikel:}

Diterima: $13 / 08 / 2021$

Disetujui: 29/09/2021

Dipublikasi: 03/10/2021

\section{Kata Kunci:}

Perikanan tangkap, alat tangkap, ramah

lingkungan, alternatif, keberlanjutan

\section{Keywords:}

Capture fisheries, fishing gears, eco-friendly, alternative, sustainable.

*Korespondensi: onespoltesa@gmail.com

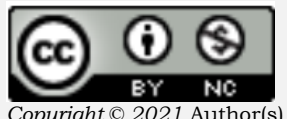

Abstrak. Perairan Kubu Raya, potensi sumberdaya perairan terutama udang galah sangat besar. Pemanfaatan sumberdaya perairan di Kabupaten Kubu Raya dilakukan dengan memanfaatkan alat tangkap yang dapat dioperasikan baik di perairan umum maupun perairan terbuka. Meskipun demikian, masalah perikanan yang dihadapi di Kabupaten Kubu Raya saat ini adalah masalah mengenai penggunaan alat tangkap yang kurang ramah lingkungan. Penggunaan pukat oleh nelayan merupakan ancaman bagi keberlanjutan sumberdaya perairan dan lingkungan. Penentuan Alternatif Alat Tangkap Ramah Lingkungan adalah cara untuk melestarikan keberlanjutan Perikanan Tangkap di Kabupaten Kubu Raya. Tujuan dari penelitian ini adalah untuk menentukan alat tangkap alternatif yang paling ramah lingkungan. Metode yang digunakan dalam penelitian ini adalah metode standarisasi fungsi nilai pada aspek teknologi, sosial hukum, ekonomi dan lingkungan. Alat tangkap yang direkomendasikan untuk kegiatan penangkapan ikan di Kubu Raya yaitu gillnet, tramellnet, pancing dan bubu. Berdasarkan hasil analisis, alat tangkap gillnet merupakan alat tangkap yang paling direkomendasikan dari segala aspek.

\begin{abstract}
Kubu Raya Waters have a lots of fishery resources and especially is a giant prawns. A fisheries utilization in Kubu Raya Regency using by fishing gears that using in common waters or open waters. However a problem of capture fisheries faced there is using of destructive fishing gears like trawls. Trawls using by fisherman is a threats for sustainable fishery resources and environments. Solutions for solved the problem of sustainable fishery resources in Kubu Raya Regency is determination eco-friendly fishing gear. The purpose of this research is determine a alternative of most eco-friendly fishing gears that recommended for fisheries activity in Kubu Raya like gillnet, tramelnet, handline and fishing trap. A method from this research using a score standarized function with many factors are technology, social policy, economic and environtments. The result of this research determined that a gillnet is a recommended fishing gears for all aspects.
\end{abstract}

\section{PENDAHULUAN}

Kabupaten Kubu Raya merupakan salah satu Kabupaten yang ada di Kalimantan Barat memiliki potensi Perikanan Tangkap yang cukup menjanjikan. Berdasarkan data statistik perikanan tangkap tahun 2015, Produksi Perikanan Kabupaten Kubu Raya sebesar 11.989,3 Ton atau 9,3 
\% dari total produksi perikanan tangkap laut di Provinsi Kalimantan Barat. Permasalahan yang dihadapi Pemerintah Daerah terutama Kabupaten Kubu Raya saat ini sangatlah kompleks, antara lain : Kerusakan/degradasi lingkungan berupa berkurangnya tutupan mangrove dan terumbu karang, destructive fishing dan illegal fishing, tingkat kemiskinan nelayan yang tinggi, sarana dan prasarana penangkapan ikan yang belum memadai, serta belum adanya regulasi/peraturan daerah mengenai pengelolaan pemanfaatan perikanan tangkap. Penangkapan ikan tidak ramah lingkungan (Destructive fishing), merupakan masalah utama pada pada bidang perikanan tangkap yang terjadi saat ini. Destructive fishing memiliki potensi berkurangnya kelestarian sumberdaya laut yang menyebabkan kesejahteraan masyarakat juga semakin berkurang (Mustasim et al., 2021). Sumberdaya laut yang semakin berkurang membuat nelayan kesulitan untuk mencari ikan, sehingga ketersediaan sumberdaya laut di pasar atau tempat pelelangan ikan semakin berkurang dan kebutuhan masyrakat akan sumberdaya laut berkurang. Berkurangnya sumberdaya laut di Perairan Kubu Raya diakibatkan oleh penggunaan alat tangkap tidak ramah lingkungan seperti trawl.

Penggunaan trawl di Kalimantan Barat masih sangat sering digunakan terutama nelayan di daerah perairan Kubu Raya. Menurut DKP (2017), penggunaan alat tangkap jenis trawl sering digunakan di daerah Sungai Kakap Kubu Raya untuk menangkap ikan-ikan bernilai ekonomis tinggi seperti tongkol, kembung, gulamah, udang dan cumi. Penggunaan trawl secara ekologis dapat merusak lingkungan dan keberlanjutan sumberdaya ikan. Penggunaan kapal gandeng dan trawl dapat merusak keberadaan potensi laut baik secara jangka pendek maupun jangka menengah (Arisandi, 2016). Pencegahan sumberdaya laut yang rusak dapat dicegah dengan menggunakan alat tangkap alternatif yang dapat diterima oleh nelayan di Kabupaten Kubu Raya. Penentuan alat tangkap alternatif diharapkan dapat mencegah kerusakan sumberdaya laut akibat alat tangkap yang tidak ramah lingkungan. Penentuan jenis alat tangkap yang tepat dan berkelanjutan dapat membantu masyarakat dalam meningkatkan keberlanjutan sumberdaya perikanan dan ekonomi masyarakat (Setyaningrum, 2013). Penentuan alat tangkap alternatif diperlukan beberapa aspek untuk memilih alat tangkap alternatif yang akan dijadikan prioritas. Sementara, pada penelitian Wiyono (2011), penentuan prioritas alat tangkap tidak dapat dilihat berdasarkan satu aspek saja tetapi harus dilakukan dengan mempertimbangkan beberapa aspek yang berpengaruh terhadap kegiatan penangkapan ikan.

\section{METODE PENELITIAN}

Penelitian ini dilaksanakan pada bulan September-November 2017 di Kabupaten Kubu Raya Provinsi Kalimantan Barat. Lokasi penelitian di 
kawasan usaha perikanan tangkap wilayah Kabupaten Kubu Raya, yang ditunjukkan pada Gambar 1.

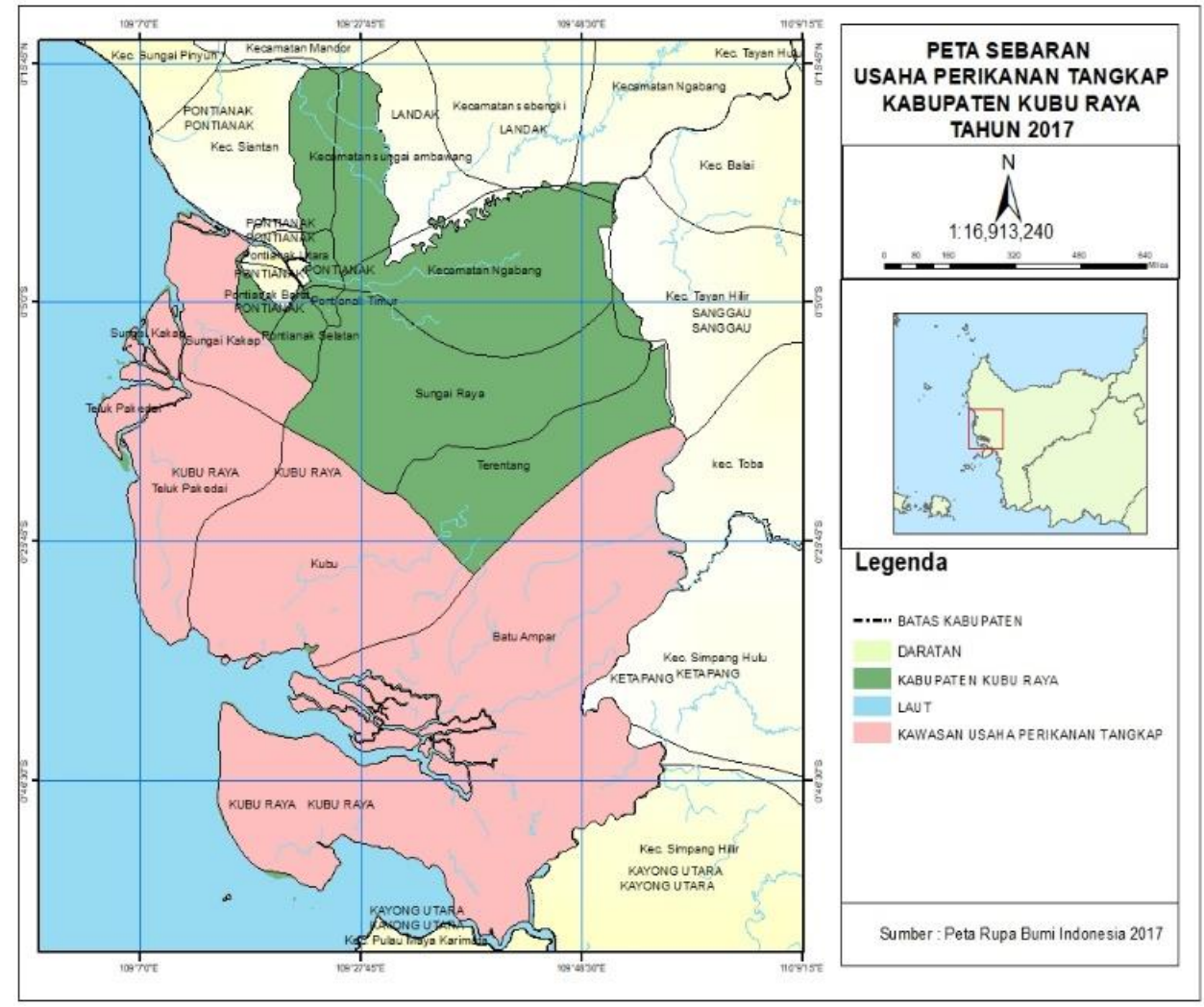

Gambar 1. Lokasi Penelitian Kabupaten Kubu Raya.

Analisis teknis meliputi analisis identifikasi kapal non ramah lingkungan (trawl) rata-rata dan kapal alternatif ramah lingkungan. Identifikasi kapal non ramah lingkungan diperoleh berdasarkan wawancara dengan nelayan dan studi literatur sedangkan identifikasi kapal ramah lingkungan diperoleh berdasarkan wawancara dan analisis skoring standarisasi nilai fungi dari 4 alat tangkap alternatif. Penentuan alat tangkap alternatif di Kabupaten Kubu Raya merupakan salah satu cara untuk meningkatkan pengelolaan perikanan tangkap secara berkelanjutan.

Alat tangkap alternatif ditentukan dengan menggunakan standarisasi fungsi nilai (Kuntora \& Listiarini 1983) dengan rumus :

$$
\begin{gathered}
V(x)=\frac{\mathrm{X}-\mathrm{Xo}}{\mathrm{X} 1-\mathrm{X} 0} \\
V(A)=\sum V i(X i)
\end{gathered}
$$

Dimana $: V(X)=$ fungsi nilai dari variable $x, x O=$ nilai terburuk $k$ riteria $; x 1=$ nilai terbaik kriteria $x ; V(A)=$ Fungsi nilai dari alternatif $A ; \operatorname{Vi}(X i)=$ fungsi nilai dari alternatif pada kriteria ke-I; $x i=$ kriteria ke-I; $I=1,2,3, \ldots, n$.

Kriteria masing-masing adalah peubah dari tiap aspek pengelolaan yang dianalisis. Aspek pengelolaan perikanan tangkap yang berkelanjutan 
yang dianalis terdiri dari aspek teknologi, sosial, ekonomi, dan lingkungan. (Tabel 1)

Tabel 1. Kriteria penilaian masing-masing aspek dalam penentuan alat tangkap alternatif

\begin{tabular}{lll}
\hline Aspek & Kriteria & Nilai \\
\hline Teknologi & Selektifitas (X1) & Tinggi (4) - Rendah (1) \\
& Kekuatan (X2) & Kuat (4) - Lemah (1) \\
& Fleksibilitas (X3) & Optimal (4) - Tidak (1) \\
& Reparasi (X4) & Ada >1 (4) - Tidak (1) \\
\hline Sosial dan hukum & Sosialisasi alat (X5) & Sering (4) - Tidak (1) \\
& Keahlian khusus (X6) & Tidak (4) - Tinggi (1) \\
& Kepuasan nelayan/diterima (X7) & Tinggi (4) - Rendah (1) \\
& Kesesuaian terhadap hukum & Tinggi (4) - Rendah (1) \\
& (X8) & \\
\hline Ekonomi & Nilai produksi (X9) & Tinggi (4) - Rendah (1) \\
& Biaya operasional (X10) & Rendah (4) - (1) Tinggi \\
& Kepemilikan pribadi (X11) & Tinggi (4) - Rendah (1) \\
& Tingkat investasi (X12) & Tinggi (4) - Rendah (1) \\
\hline Lingkungan & kuota ikan tertangkap (X13) & Banyak (4) - Sedikit (1) \\
& Target catch (X14) & Tinggi (4) - Rendah (1) \\
& Keragaman spesies (X15) & Tinggi (4) - Rendah (1) \\
& By catch (X16) & Rendah (4) - Tinggi (1)
\end{tabular}

Sumber : Analisis AHP dan Identifikasi aspek perikanan tangkap berkelanjutan

\section{HASIL DAN PEMBAHASAN}

Berdasarkan penelitian yang telah dilakukan diperoleh beberapa penilaian untuk menentukan alat tangkap alternatif berdasarkan beberapa aspek antara lain :

1. Penilaian aspek teknologi

Aspek teknologi merupakan aspek yang mendukung usaha perikanan tangkap. Perikanan tangkap yang efektif dan berkelanjutan memerlukan alat tangkap yang selektif dan didukung dengan adanya fasilitas doking, alat bantu serta ukuran kapal yang optimal. Penilaian dari aspek ini berpengaruh terhadap penggunaan alat tangkap yang efektif dari segi teknologi. Selengkapnya, penilaian dari aspek teknologi tersaji pada Tabel 2

Tabel 2. Penilaian aspek teknologi

\begin{tabular}{lcccc}
\hline Alat tangkap & $\mathrm{X} 1$ & $\mathrm{X} 2$ & $\mathrm{X} 3$ & $\mathrm{X} 4$ \\
\hline Gillnet & 3,55 & 3,35 & 2,45 & 2,05 \\
Tramelnet & 3,30 & 3,15 & 2,35 & 2,20 \\
Pancing/rawai & 3,40 & 2,55 & 2,00 & 1,75 \\
Bubu/perangkap & 3,33 & 1,95 & 3,40 & 3,15 \\
\hline
\end{tabular}


Sumber : Hasil pengisian kuesioner oleh nelayan

Berdasarkan penilaian aspek teknologi, gillnet memiliki nilai selektifitas tertinggi. Hal ini dikarenakan sebagian besar ikan yang tertangkap oleh gillnet merupakan hasil tangkapan yang layak tangkap. Ikan layak tangkap terjerat/terpuntal oleh mesh size yang telah dirancang secara khusus agar tidak ada ikan-ikan tidak layak tangkap yang terjerat/terpuntal oleh gillnet. Selain itu alat tangkap gillnet juga memiliki kekuatan yang tinggi sehingga tidak mudah koyak. Menurut Safitri \& Adelita (2018), hingga saat ini alat tangkap gillnet yang dioperasikan oleh nelayan di Pelabuhan Perikanan Nusantara (PPN) Pemangkat sangat selektif digunakan untuk menangkap ikan-ikan pelagis seperti kembung, tongkol dan layang. Bahan dari alat tangkap gillnet terbuat dari benang pilihan yang kuat dan tahan lama. Alat tangkap bubu memiliki flexibilitas yang tinggi, sehingga mudah untuk dioperasikan dimana saja baik perairan umum maupun perairan laut. Meskipun demikian alat tangkap bubu mudah rusak dikarenakan terpaan arus kuat serta kekuatan capit kepiting yang dapat merusak bubu. Untuk mengetahui alat tangkap yang menjadi prioritas alternatif perlu dilakukan standarisasi fungsi dari nilai X yaitu V. Lebih jelasnya dapat dilihat pada Tabel 3.

Tabel 3. Standarisasi fungsi nilai aspek teknologi

\begin{tabular}{lcccccc}
\hline Alat tangkap & V1 & V2 & V3 & V4 & VA & Prioritas \\
\hline Gillnet & 1,000 & 1,000 & 0,321 & 0,214 & 2,536 & 1 \\
Tramelnet & 0,000 & 0,857 & 0,250 & 0,321 & 1,429 & 3 \\
Pancing/rawai & 0,400 & 0,429 & 0,000 & 0,000 & 0,829 & 4 \\
Bubu/perangkap & 0,120 & 0,000 & 1,000 & 1,000 & 2,120 & 2 \\
\hline
\end{tabular}

Sumber : Hasil perhitungan fungsi nilai $\mathrm{X}$

Berdasarkan Tabel 3, alat tangkap yang menjadi prioritas menurut aspek teknologi adalah alat tangkap gillnet dengan VA 2,536 diikuti oleh bubu/perangkap $(2,120)$ dan pancing dengan prioritas terakhir. Menurut Setyaningrum (2013), semakin tinggi teknologi yang digunakan pada suatu alat tangkap maka tingkat selektivitas yang digunakan juga semakin tinggi.

2. Penilaian aspek sosial dan hukum

Aspek sosial dan hukum merupakan aspek utama dalam pengelolaan perikanan tangkap yang berkelanjutan. Secara sosial, kegiatan usaha penangkapan ikan dapat berjalan dengan baik jika stakeholder bisa memanfaatkan penggunaan alat tangkap secara baik dan maksimal sesuai dengan peraturan hukum dan perundang-undangan. Agar alat tangkap bisa digunakan secara optimal maka dibutuhkan sebuah keahlian, dimana diperlukan peran pemerintah dalam melakukan sosialisasi alat tangkap kepada nelayan. Penilaian aspek sosial, selengkapnya tersaji pada Tabel 4 
Tabel 4 Penilaian aspek sosial dan hukum

\begin{tabular}{lcccc}
\hline Alat tangkap & X5 & X6 & X7 & X8 \\
\hline Gillnet & 2,45 & 2,40 & 2,80 & 3,20 \\
Tramelnet & 2,45 & 2,30 & 2,75 & 2,95 \\
Pancing/rawai & 2,15 & 2,45 & 1,80 & 3,40 \\
Bubu/perangkap & 1,90 & 3,25 & 1,85 & 2,05
\end{tabular}

Sumber : Hasil pengisian kuesioner oleh nelayan

Kegiatan sosialisasi mengenai alat tangkap gillnet dan tramelnet merupakan merupakan kegiatan yang paling sering diselenggarakan oleh Dinas Perikanan Kabupaten Kubu Raya. Upaya pengelolaan perikanan tangkap berkelanjutan Dinas Perikanan Kabupaten Kubu Raya telah melakukan sosialisasi dan upaya penggantian alat tangkap trawl ke gillnet secara menyeluruh dan bertahap. Mengoperasikan Gillnet dan Tramelnet diperlukan keahlian khusus, sehingga dalam hal ini sangat diperlukan sosialisasi mengenai pengoperasian alat tangkap. Selain itu, alat tangkap gillnet telah diterima oleh sebagian besar nelayan sebagai alat tangkap alternatif pengganti trawl. Alat tangkap gillnet memiliki kriteria yang sesuai dan layak menurut hukum, meskipun secara penilaian berdasarkan aspek sosial alat tangkap pancing/rawai lebih sesuai dan layak. Mengetahui alat tangkap alternatif yang sesuai berdasarkan aspek sosial dapat dilihat dari standarisasi fungsi nilai pada Tabel 5.

Tabel 5. Standarisasi fungsi nilai aspek sosial dan hukum

\begin{tabular}{lcccccc}
\hline Alat tangkap & V5 & V6 & V7 & V8 & VA & Prioritas \\
\hline Gillnet & 1,000 & 0,105 & 1,000 & 0,852 & 2,957 & 1 \\
Tramelnet & 1,000 & 0,000 & 0,950 & 0,667 & 2,617 & 2 \\
Pancing/rawai & 0,455 & 0,158 & 0,000 & 1,000 & 1,612 & 3 \\
Bubu/perangkap & 0,000 & 1,000 & 0,050 & 0,000 & 1,050 & 4
\end{tabular}

Sumber : Hasil perhitungan fungsi nilai $\mathrm{X}$

Berdasarkan Tabel 5, alat tangkap yang menjadi prioritas alternatif berdasarkan aspek sosial dan hukum adalah gillnet dengan VA 2,957, diikuti tramelnet $(2,617)$, pancing/rawai $(1,612)$ dan bubu/perangkap (1,050). Menurut Suman (2017), aspek sosial seperti status pekerjaan utama nelayan, umur nelayan, status kepemilikan unit alat tangkap dan kelengkapan administrasi unit alat tangkap dapat berpengaruh nyata terhadap keberlangsungan kegiatan penangkapan ikan.

3. Penilaian aspek ekonomi

Penilaian aspek ekonomi digunakan untuk mengetahui besarnya nilai produksi, biaya operasional, rasio kepemilikan, dan tingkat investasi dari sebuah unit alat tangkap. Beberapa kriteria pada aspek ekonomi dijadikan sebagai acuan dalam penggunaan alat tangkap yang efisien dan 
menguntungkan secara ekonomis. Lebih jelasnya penilaian aspek ekonomi untuk menentukan alat tangkap alternatif dapat dilihat pada Tabel 6.

Tabel 6. Penilaian aspek ekonomi

\begin{tabular}{lcccc}
\hline Alat tangkap & X9 & X10 & X11 & X12 \\
\hline Gillnet & 3,50 & 1,85 & 2,35 & 3,00 \\
Tramelnet & 3,25 & 1,60 & 2,45 & 3,00 \\
Pancing/rawai & 3,00 & 3,70 & 3,80 & 2,20 \\
Bubu/perangkap & 3,00 & 3,50 & 3,30 & 2,45
\end{tabular}

Sumber : Hasil pengisian kuesioner oleh nelayan

Pada Tabel 6, dapat dilihat bahwa alat tangkap gillnet memiliki nilai produksi yang tinggi, sehingga secara investasi juga tinggi. Dari segi biaya operasional alat tangkap gillnet dan tramelnet jauh lebih tinggi dibandingkan dengan alat tangkap pancing/rawai dan bubu/perangkap. Begitu juga secara kepemilikan alat tangkap pancing/rawai dan bubu/perangkap lebih bisa dimiliki secara pribadi oleh pelaku usaha perikanan tangkap (nelayan). Untuk mengetahui prioritas alat tangkap alternatif perlu dilakukan standarisasi fungsi nilai yang tersaji pada Tabel 7 .

Tabel 7. Standarisasi fungsi nilai aspek ekonomi

\begin{tabular}{lcccccc}
\hline Alat tangkap & V9 & V10 & V11 & V12 & VA & Prioritas \\
\hline Gillnet & 1,000 & 0,119 & 0,000 & 1,000 & 2,119 & 1 \\
Tramelnet & 0,500 & 0,000 & 0,069 & 1,000 & 1,569 & 4 \\
Pancing/rawai & 0,000 & 1,000 & 1,000 & 0,000 & 2,000 & 2 \\
Bubu/perangkap & 0,000 & 0,905 & 0,655 & 0,313 & 1,872 & 3 \\
\hline
\end{tabular}

Sumber : Hasil perhitungan fungsi nilai $\mathrm{X}$

Berdasarkan Tabel 7, secara aspek ekonomi alat tangkap gillnet menjadi prioritas utama sebagai alat tangkap alternatif pengganti trawl $(2,119)$, diikuti pancing $(2,000)$, bubu/perangkap $(1,872)$ dan tramelnet $(1,569)$. Meskipun alat tangkap gillnet memerlukan biaya operasional besar dan belum bisa sepenuhnya oleh nelayan, alat tangkap gillnet berpotensi menghasilkan nilai produksi yang besar dan tingkat investasi yang tinggi, sehingga dapat menutupi segala biaya operasional penggunaan alat tangkap. Menurut Hargianto et al., (2016), alat tangkap dengan biaya operasional rendah dapat menguntukan nelayan secara ekonomi. Secara ekonomi alat tangkap jaring insang juga sangat menguntungkan bagi nelayan yang beroperasi di wilayah perairan Ketapang dimana wilayah tersebut berbatasan langsung dengan perairan Kubu Raya (Setiawati et al., 2015).

4. Penilaian aspek lingkungan

Aspek lingkungan adalah aspek yang sangat penting dalam pengelolaan perikanan tangkap berkelanjutan. Secara ekologis alat tangkap ramah lingkungan dapat dilihat dari besarnya kuota ikan yang tertangkap 
tanpa merusak lingkungan, ikan hasil tangkapan utama yang tertangkap (target catch) dan keragaman spesies yang tertangkap tanpa terdapat ikan tangkapan yang dilindungi/bukan hasil tangkapan utama (by catch). Penilaian aspek lingkungan dapat dilihat pada Tabel 8.

Tabel 8. Penilaian aspek lingkungan

\begin{tabular}{lllll}
\hline Alat tangkap & X13 & X14 & X15 & X16 \\
\hline Gillnet & 3,50 & 3,45 & 3,60 & 2,75 \\
Tramelnet & 2,90 & 3,20 & 3,50 & 3,50 \\
Pancing/rawai & 1,90 & 3,75 & 1,80 & 3,80 \\
Bubu/perangkap & 2,70 & 3,45 & 2,20 & 3,55 \\
\hline
\end{tabular}

Sumber : Hasil pengisian kuesioner oleh nelayan

Pada tabel 8 terlihat bahwa, pada alat tangkap gillnet kuota ikan yang tertangkap, ikan target utama yang tertangkap, dan keragaman spesies yang tertangkap lebih tinggi dari ketiga alat tangkap lain, Sedangkan untuk by-catch yang tertangkap, alat tangkapan pancing menangkap ikan by-catch paling sedikit. Penentuan alat tangkap alternatif berdasarkan aspek lingkungan dapat dilihat pada Tabel 9.

Tabel 9. Standarisasi fungsi nilai aspek lingkungan

\begin{tabular}{lcccccc}
\hline Alat tangkap & V13 & V114 & V15 & V16 & VA & Prioritas \\
\hline Gillnet & 1,000 & 0,455 & 1,000 & 0,000 & 2,455 & 1 \\
Tramelnet & 0,625 & 0,000 & 0,944 & 0,714 & 2,284 & 2 \\
Pancing/rawai & 0,000 & 1,000 & 0,000 & 1,000 & 2,000 & 3 \\
Bubu/perangkap & 0,500 & 0,455 & 0,222 & 0,762 & 1,939 & 4 \\
\hline
\end{tabular}

Sumber : Hasil perhitungan fungsi nilai $\mathrm{X}$

Berdasarkan standarisasi fungsi nilai aspek lingkungan, alat tangkap gillnet merupakan prioritas utama dari alat tangkap alternatif dengan VA 2,455, diikuti oleh tramelnet $(2,284)$, pancing/rawai $(2,000)$ dan bubu/perangkap $(1,939)$.

5. Gabungan penilaian aspek teknologi, ekonomi, sosial hukum dan lingkungan

Secara keseluruhan alat tangkap gillnet menjadi prioritas utama dari segala aspek baik teknologi, sosial dan hukum, ekonomi dan lingkungan. Meskipun demikian, perlu diketahui alat tangkap alternatif lain sebagai strategi pengelolaan perikanan tangkap yang berkelanjutan. Alat tangkap alternatif disesuaikan berdasarkan alat tangkap ramah lingkungan eksisting di setiap wilayah di Kabupaten Kubu Raya. Alat tangkap alternatif untuk beberapa daerah pengguna alat tangkap eksisting non trawl ditentukan berdasarkan penilaian gabungan dari beberapa aspek pada Tabel 10. 
Tabel 10. VA Gabungan aspek teknologi, ekonomi, sosial hukum dan lingkungan

\begin{tabular}{lcccc}
\multicolumn{1}{c}{ Alat tangkap } & Teknologi & Sosial \& hukum & Ekonomi & Lingkungan \\
\hline Gillnet & 2,536 & 2,265 & 2,119 & 2,455 \\
Tramelnet & 1,429 & 2,617 & 1,569 & 2,284 \\
Pancing/rawai & 0,829 & 1,543 & 2,000 & 2,000 \\
Bubu/perangkap & 2,120 & 1,050 & 1,872 & 1,939 \\
\hline
\end{tabular}

Sumber : Total V (VA) pada masing-masing aspek

Setelah diketahui nilai VA gabungan dari masing-masing aspek, selanjutnya dilakukan standarisasi nilai terhadap beberapa VA masingmasing aspek. standarisasi nilai terhadap beberapa VA masing-masing aspek disajikan pada Tabel 11 .

Tabel 11. Standarisasi VA gabungan aspek teknologi, ekonomi, sosial hukum dan lingkungan

\begin{tabular}{lcccccc}
\hline \multicolumn{1}{c}{ Alat tangkap } & $\begin{array}{c}(\mathrm{V}) \\
\text { Teknologi }\end{array}$ & $\begin{array}{c}\text { (V) } \\
\text { Sosial \& } \\
\text { hukum }\end{array}$ & $\begin{array}{c}\text { (V) } \\
\text { Ekonomi }\end{array}$ & $\begin{array}{c}\text { Lingku } \\
\text { ngan }\end{array}$ & $\begin{array}{c}\text { (VA) } \\
\text { Gabungan }\end{array}$ & Prioritas \\
\hline Gillnet & 1,000 & 0,775 & 1,000 & 1,000 & 3,775 & 1 \\
Tramelnet & 0,351 & 1,000 & 0,000 & 0,669 & 2,020 & 2 \\
Pancing/rawai & 0,000 & 0,314 & 0,784 & 0,119 & 1,217 & 4 \\
Bubu/perangkap & 0,756 & 0,000 & 0,552 & 0,000 & 1,308 & 3 \\
\hline
\end{tabular}

Sumber : Hasil standarisasi VA pada masing-masing aspek

Berdasarkan standarisasi nilai VA pada masing-masing aspek alat tangkap alternatif yang menjadi prioritas adalah Gillnet. Berdasarkan identifikasi alat tangkap dominan dan jenis yang dominan tertangkap di Perairan Laut Kabupaten Kubu Raya, alat tangkap gillnet dan tramell net sangat sesuai dioperasikan di Kecamatan Sungai Kakap dan Teluk Pakedai, dimana kedua daerah tersebut memiliki potensi perikanan yang sangat beragam dan bernilai ekonomis tinggi seperti layur, gulama, tembang, tongkol, cucut, mayung, udang, cumi dan hasil tangkapan ikan bernilai ekonomis tinggi lainnya. Ikan-ikan bernilai potensi tinggi di Kecamatan Sungai Kakap dan Teluk Pakedai sangat sesuai dengan alat tangkap gillnet dan tramelnet yang sebagian besar nelayannya masih menggunakan trawl.

Kecamatan Batu Ampar dan Kubu memiliki potensi ikan gulama dan udang krosok yang sangat besar, dengan memanfaatkan alat tangkap tramell net, perangkap kepiting (bubu), jala tebar, dan pukat rajungan. Untuk mengoptimalkan potensi perikanan di wilayah Kecamatan Batu Ampar dan Teluk Pakedai, maka pengoperasian alat tangkap tramell net dan perangkap kepiting perlu dimaksimalkan. Selain itu alat tangkap pancing/rawai juga dapat digunakan sebagai solusi alternatif dalam memanfaatkan potensi sumberdaya perikanan yang berkelanjutan. 


\section{KESIMPULAN}

Kesimpulan dari penelitian ini adalah alat tangkap gillnet merupakan alat tangkap alteratif setelah trammelnet, pancing rawai dan perangkap bubu yang dapat dijadikan prioritas dalam penangkapan ikan secara berkelanjutan jika ditinjau dari beberapa aspek.

\section{DAFTAR PUSTAKA}

Arisandi, A. (2016). Inkonsistensi Kebijakan Penggunaan Jaring Trawl (Studi Kasus Penggunaan Jaring Trawl oleh Nelayan Wilayah Perairan Gresik). JKMP (Jurnal Kebijakan dan Manajemen Publik), 4(1), 1-18.

Dinas Kelautan dan Perikanan Kalimantan Barat. (2017). Analisis Kebijakan Pengelolaan Perikanan Tangkap yang Berkelanjutan di Kabupaten Kubu Raya.

Hargianto, I. T., Anggawangsa, R. F., \& Wudianto, W. (2016). Perikanan pancing ulur di Palabuhanratu: Kinerja Teknis Alat Tangkap. Jurnal Penelitian Perikanan Indonesia, 19(3), 121-130.

Kementerian Kelautan dan Perikanan. (2015). Analisis Data Pokok Kelautan dan Perikanan Pusat Data dan Informasi Statistik. Kementerian Kelautan dan Perikanan. Jakarta.

Mustasim, M., Gunaisah, E., Ulat, M. A., Handayani, H., Ismail, I., Suruwaky, A. M., ... \& Poltak, H. (2021). PELATIHAN PEMBUATAN ALAT PENANGKAPAN IKAN RAMAH LINGKUNGAN. Mitra Mahajana: Jurnal Pengabdian Masyarakat, 2(1), 41-48.

Safitri, I., \& Adelita, K. (2018). Perikanan Tangkap Gillnet di Pelabuhan Perikanan Nusantara (PPN) Pemangkat Kalimantan Barat. Jurnal Laut Khatulistiwa, 1(1), 19-24.

Setiawati, B., Wijayanto, D., \& Pramonowibowo. (2015). Analisis Faktor Produksi Hasil Tangkapan Ikan Kembung (Rastrelliger SP) Pada Alat Tangkap Drift Gill Net Di Kab. Ketapang, Kalimantan Barat. Journal of Fisheries Resources Utilization Management and Technology, 4(2), 40-48.

Setyaningrum, E. W. (2013). Penentuan Jenis Alat Tangkap Ikan Pelagis

yang Tepat dan Berkelanjutan dalam Mendukung Peningkatan Perikanan Tangkap di Muncar Kabupaten Banyuwangi Indonesia. Indonesian Journal of Environment and Sustainable Development, 4(2), 45-50.

Suman, A. (2017). Alat tangkap udang dogol (Metapenaeus ensis De Haan) yang layak dikembangkan di perairan Cilacap dan sekitarnya. Jurnal Penelitian Perikanan Indonesia, 12(2), 129-137.

Wiyono, E. S. (2011). Alat Tangkap Unggulan di Kabupaten Bangka Selatan Provinsi Bangka Belitung. Buletin PSP, 19(3), 230-238. 